\title{
УДК 35.07:323.2
}

\section{DOI: $10.34132 /$ pard2021.13.07}

\section{СОЦІАЛЬНА ДОВІРА ДО ОРГАНІВ ПУБЛІЧНОЇ ВЛАДИ ЯК ФАКТОР РОЗВИТКУ ГРОМАДЯНСЬКОГО СУСПІЛЬСТВА}

Палагнюк Ю.В., д-р наук з держ. упр., професор, завідувач кафедри соціальної роботи, управління і педагогіки, Інститут державного управління, Чорноморський національний університет імені Петра Могили, м. Миколаїв, Україна.

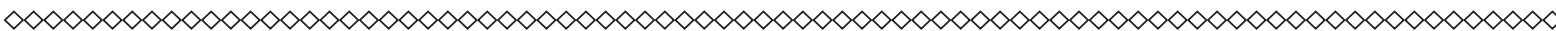

У даній науковій статті розглянуто взаємозв'язок між сочуіальною довірою до органів публічної влади та розвитком громадянського суспільства в умовах проведення реформ у різних сфрерах в сучасній Україні. Розглянуто сутність таких ключових понять, як «довіра», «соитіальна довіра», зокрема у новітніх дослідженнях західних вчених. Проаналізовано рівень сочіальной довіри до різних соціальних інститутів у 2020-2021 роках відповідно до міжнародного моніторингового проєкту World Values Survey, a також украӥнських соціологічних изентрів. Показано, щуо низький рівень сочіальної довіри, у тому числі, до органів публічної влади, є наслідком негативного досвіду участі украӥниів у довірчих відносинах з изими соціальними інститутами. Наголомено, щуо в останні роки в Україні збільиується сочіальна довіра до волонтерських організаціий $і$ до органів місцевого самоврядування. Це є одним із позитивних аспектів реформи децуентралізації, свідченням розвитку громадянського суспільства на рівні розвитку громади.

Ключові слова: соціальна довіра, довіра, громадянське суспільство, громадська думка, публічна влада, демократія, децентралізачія, територіальна громада.

Постановка проблеми у загальному вигляді. В ситуації уваги до розбудови громадянського суспільства взагалі та в сучасній 
Україні зокрема особливої ваги набувають такі поняття, як довіра та солідарність, які виступають важливими складовими соціального капіталу, сталості демократичної політичної системи.

Проблема соціальної довіри до різних соціальних інститутів стає однією з найбільш актуальних в Україні сьогодення в умовах окупації частини Донбасу та АР Крим, збройного конфлікту на сході нашої держави, політичної невизначеності, погіршення соціально-економічного становища громадян, проведення реформ у різних сферах, зокрема у медичній, освітніх сферах, реформи децентралізації. Несподівані зміни не на краще у різних сферах життя підривають довіру людей до суспільних інститутів, що відповідно несе деструктивний вплив на функціонування окремих сфер суспільно-політичного життя. Загалом низький рівень соціальної довіри порушує основи соціальних відносин, що негативно позначається на різних аспектах функціонування суспільства. Відтак актуальність вивчення проблематики соціальної довіри до органів публічної влади в сучасній Україні диктується необхідністю пошуку дієвих соціальних взаємодій і мінімізації ризиків в умовах сучасних соціально-економічних, політичних та безпекових викликів.

Аналіз останніх досліджень і публікацій. Соціальний зміст довіри та іiі роль в суспільстві досліджують значна кількість закордонних вчених, наприклад, К. Вальєр, М. Вебер, Т. Срл, Т. Цвєтковіч тощо. При цьому соціальна довіра є одним з головних понять концепції соціального капіталу (Дж. Коулмен, П. Бурдьє, Р. Патнем, П. Штомпка, Ф. Фукуяма та інші). Її представники розглядають концепт «Соціальної довіри» як передумову та підгрунтя соціального капіталу, а також його продукт.

Основна частина досліджень соціальної довіри належить дослідникам 3 політичних наук, соціологам і філософам. При цьому політологи вивчають довіру в основному засновуючись на соціологічних опитуваннях того як люди довіряють своєму уряду, органам публічної влади, політикам, одне одному. Проблематика довіри та соціальної довіри представлена у роботах таких українських дослідників різних галузей наук, як: Є. Головаха, О. Кожем'якіна, Н. Костенко, О. Кучабський, С. Липов, С. Макєєв, О. 
Макух, С. Наумкіна, Т. Пояркова, С. Погорєлий, В. Письменний, В. Печерський, С. Серьогін, Т. Стеценко, С. Тимофєєв, К. Урсуленко та інших. Незважаючи на значну кількість робіт, ступінь наукової розробленості теми соціальної довіри характеризується теоретичною фрагментарністю.

Формулювання цілей статті (постановка завдання). Метою дослідження $\epsilon$ обгрунтування взаємозв'язку між соціальною довірою до органів публічної влади та розвитком громадянського суспільства в умовах проведення реформ у різних сферах в сучасній Україні.

Виклад основного матеріалу дослідження. Перш ніж перейти до реалізації поставленої мети, спочатку доцільно розглянути сутність таких ключових понять, як «довіра», «соціальна довіра».

За визначенням відомого американського філософа Ф. Фукуями у роботі «Довіра: соціальні чесноти та шлях до процвітання», довіра - це «виникаюче у членів співтовариства очікування того, що інші його члени будуть поводитись більш-менш передбачувано, чесно та з увагою до потреб оточуючих, у відповідності з деякими загальними нормами» [3, с. 52]. Отже, за Ф. Фукуямою, довіра виникає у рамках певного суспільства як очікування того, що його члени будуть поводити себе нормально й чесно, виявляючи готовність до взаємодопомоги відповідно до визнаних у суспільстві норм. При цьому дослідник виокремлює три основних шляхи іï прояву: перший - заснований на сім'ї та родинних стосунках, другий на добровільних асоціаціях позародинного типу (наприклад, навчальних закладах різних рівнів освіти, клубах, професійних організаціях тощо), третій - держава. Також Ф. Фукуяма наголошує, що різні суспільства мають різний потенціал довіри та солідарності, оскільки останні мають переважно культурну природу [3, с. 109]. Відповідно, через культурну природу різних суспільств рівень довіри у суспільствах може значно відрізнятися. При цьому, другий шлях проявів довіри, а саме добровільні асоціації позародинного типу - $\epsilon$ властивим для громадянського суспільства. Тому тут простежується взаємозв'язок між добровільними асоціаціями та рівнем розвитку громадянського суспільства. 
Отже, виходячи з вищезазначеного, слід наголосити на тому, що довіра є базовим елементом громадянського суспільства. Адже засадничими для громадянського суспільства є добровільні форми асоціацій, які існують поза державою. Такого роду спільності в своїй основі як обов'язковий елемент мають саме довіру, яка створює сприятливу атмосферу для розвитку співробітництва та взаємодії. [9, с. 11]

Суттєвий внесок у розвиток сутності довіри зробив відомий американський політолог, професор Урядової школи Джона Ф. Кеннеді Гарвардського університету та розробник власної концепції соціального капіталу Р. Патнем. Разом із колегами Р. Леонарді та Р. Нанетті він зазначає, що в суспільстві, де люди довіряють тільки своїм родичам і не схильні до кооперації з іншими, спостерігається економічна стагнація. Тому довіра є однією 3 тих невід'ємних якостей особистості, які підвищують іï добробут i виявляються лише в процесі колективної діяльності [16, с. 136]. При цьому важливим $\epsilon$ те, що довіра може розглядатися і як джерело, i як результат соціального капіталу.

3 розвитком економіки пов'язує існування довіри у суспільстві доктор економічних наук В. Липов. На його думку, - це історично усталена та постійно відтворювана система соціальних відносин, що забезпечує його інтегрованість і виконує функцію взаємопов'язаність інституційних елементів довіри між основними підсистемами суспільства - ідеології, політики, права та економіки [11, с. 18-19]. Наголосимо, що лише на основі опори на специфічні особливості базових інститутів можливе формування атмосфери соціальної довіри в суспільстві.

Серед інших вітчизняних дослідників є науковий інтерес до визначення сутності і значенні довіри для розвитку суспільства. Так, наприклад, на переконання кандидата філософських наук О. Кожем’якіної, довіра - це «складне ієрархічне соціальне явище, що відображає певне ціннісне відношення, яке має характер очікування бажаного результату потенційно некерованих взаємодій та базується на упевненості в правильності та ефективності дій об’єкта довіри, визнанні його діяльності як відповідної певним 
етичним вимогам (чесності, відповідальності, професійної компетентності та ін.)». [9, с. 11]. Тобто довіра пов'язана 3 етичними, правильними та ефективними діями об'єкта довіри. На думку кандидата соціологічних наук Т. О. Стеценко, негативний досвід невиправдання довіри є важливим бар'єром для формування довірчих відносин і подальшого накопичення соціального ресурсу довіри у суспільстві. Незалежно від обсягу ресурсу довіри у певному суспільстві в певний період його розвитку, соціальна система і життя людини диктують необхідність здійснювати вибір на постійній основі, а отже знову й знову вирішувати для себе яку позицію обрати щодо різних об'єктів соціальної реальності - довіри чи недовіри $[18$, с. 8$]$. Слід зазначити, що вибір довіряти чи ні ми робимо на постійній основі, і на основі цього формується або ні ресурс довіри у суспільстві.

У контексті зазначеного вище відзначимо, що довіра пов'язана також з поняттям ризику і рівнем невизначеності та невпевненості людини у суспільстві і конкретно до об'єкта довіри. Це відбувається тому, що «довіру відрізняє певний ступінь вірогідності, що приводить до ризику, адже вона виникає, на відміну від упевненості, в ситуації невизначеності, недостатності або відсутності потрібної інформації та певних гарантій, що посилює ризик, водночас даючи шанс побудови нових стосунків» [9, с. 14]. Можна говорити про те, що це $\epsilon$ проявом патерналістського суспільства через цілковите покладання на іншу людину, суспільні інститути, а відповідно - на їх бажання чи небажання реалізувати взяті зобов'язання.

Слід наголосити, що в умовах нестабільності в різних сферах суспільного-політичного та соціально-економічного життя в незалежній Україні, роль довіри як ресурсу, який направлений на забезпечення стійкості, порядку і стабільності суспільної системи загалом, а також окремих її сфер, вагома. Отож необхідно розвивати культуру довіри на принципах взаємовигідного співробітництва та соціальної відповідальності. Це забезпечить попередження глобальних i локальних ризиків, розвиток дієвого соціального діалогу, сприятиме підвищенню якості життя населення [12, с. 64]. Відповідно, пов'язаним з соціальною довірою концептом є соціальна 
відповідальність. Вчені Т. Костєва та О. Файчук пов'язують соціальну відповідальність органів місцевого самоврядування як один із факторів розвитку громадянського суспільства. Однак, вони роблять висновок у результаті досліджень тенденцій розвитку сіл та ОТГ Миколаївського району, що тенденції відрізняються від тих цінностей та стандартів європейського характеру у побудові громадянського суспільства та соціальної відповідальності на рівні місцевого самоврядування, проголошених Україною на початку реформи децентралізації [7, с. 71-72].

Якщо говорити про структуру довіри, то до неї вчені відносять довірчі очікування, що містять бажаний результат соціальної взаємодії, поєднуючи в собі раціональний, емоційний та етичний компоненти, а також саму реалізацію діяльності в напрямку досягнення бажаного результату. Як правило, виокремлюють три види довіри: до себе, до інших людей, до світу. Також виділяють довіру міжособистісну як довіру до людей та інституціональну як довіру до абстрактних систем [9, с. 11].

У 2021 р. західними вченими було проведене комплексне дослідження соціальної довіри у сучасних умовах розвитку суспільства, яке було презентовано у формі колективної монографії під назвою «Соціальна довіра» за редакцією К. Вальєра та М. Вебера. Вони стверджують, що їх результати не дають жодних доказів існування норми довіри. Більш того, дані їх дослідження свідчать про те, що немає ніякої різниці у нормативних переконаннях людей щодо довіри друзям та незнайомцям. Найчастіше норми є контекстуальними, оскільки вони охоплюють лише певний клас ситуацій. Наприклад, може бути так, що існує загальний обов'язок довіряти друзям, але не чужим людям. Однак, дослідження показали, що навіть у близьких взаємовідносинах, довіра, здається, нормативно не вимагається. Більш того, довіра грунтується на нормах взаємності. Саме існування довіри дає підстави для очікування взаємності. Ми очікуємо, що люди, яким ми допомагали, будуть допомагати й нам. Відповідно, ми очікуємо від тих, кому ми довіряємо, мати зобов'язання шанувати нашу довіру. Саме з цієї причини ми стверджуємо, що довіра може бути раціональною настільки, наскільки 
одна людина своїми діями очікує від іншої людини відповідати нормі взаємності i, таким чином, викликати у неї адекватну реакцію на свої дії. Таким чином, результати дослідження цих західних вчених говорять про те, що існує присутність норми взаємності, яка викликає довірчу поведінку в безособовому контексті. Цікавим $\epsilon$ той факт, що люди, яким проявляють довіру, зазвичай повертають свою довіру у такому ж або у меншому об'ємі. Такий взаємозв'язок між людьми у взаєминах, заснованих на довірі, також може бути прояснений теорією дотримання норм, згідно з якою відповідність залежить від наявності належних очікувань [24, с. 41-42].

Після визначення поняття та сутності довіри та недовіри, причин їх виникнення та ролі у сучасному суспільстві перейдемо до характеристики концепту «соціальна довіра».

У соціології соціальна довіра розглядається як одна з передумов соціального порядку в суспільстві, результат соціальної дії, одна 3 умов соціального обміну, як структурний компонент соціального капіталу, принцип конструювання соціальних відносин. Виокремлюють два види соціальної довіри: міжособистісна та довіра до соціальних інститутів. [23] Причому обидва види соціальної довіри пов'язані з довірою до органів публічної влади та з розвитком громадянського суспільства.

Загалом дослідники соціальної довіри в контексті соціального капіталупов'язують його з розвиненим громадянським суспільством, дотриманням прав і свобод людини та громадянина, демократією, економічним процвітанням, що актуалізується в контексті заявлених цілей сталого розвитку України на період до 2030 року, таких як: сприяння побудові миролюбного и відкритого суспільства в інтересах сталого розвитку, забезпечення доступу до правосуддя для всіх і створення ефективних, підзвітних та заснованих на широкій участі інституцій на всіх рівнях; сприяння поступальному, всеохоплюючому та сталому економічному зростанню, повній i продуктивній зайнятості та гідній праці для всіх; зміцнення засобів здійснення й активізація роботи в рамках глобального партнерства в інтересах сталого розвитку; забезпечення всеохоплюючої i справедливої якісної освіти та заохочення можливості навчання 
впродовж усього життя для всіх; забезпечення здорового способу життя та сприяння благополуччю для всіх у будь-якому віці тощо [22]. Виявлення соціального капіталу, джерел ефективної взаємодії людей та органів публічної влади, що заснована на соціальній довірі до інститутів, зумовлюють потужний дослідницький інтерес до зазначеної проблематики.

Як вже було зазначено вище, із сучасних досліджень західних вчених слід назвати колективну роботу авторів під редакцією К. Вальєра та М. Вебера «Соціальна довіра» (2021). Соціальна довіра у цій праці визначається як довіра до чужих людей, тобто до тих людей у суспільстві, з якими людина мало знайома. Таким чином, соціальну довіру можна розуміти у широкому сенсі як довіру в суспільстві. Соціальна довіра - це довіра, коли люди дотримуються суспільних норм, які $€$ загальновизнаними, а також спільних соціальних правил, яких люди, по-перше, очікують дотримання одне від одного, i, по-друге, вважають, що кожен морально повинен їх дотримуватися.

Відповідно соціальна довіра створює середовище практичної та стратегічної стабільності. Через те, що люди у довірчих суспільствах загалом вірять у те, що інші члени суспільства будуть дотримуватися цих суспільних норм, вони можуть формулювати проєкти і плани з достатньою впевненістю. Більш того, соціальну довіру у сучасному суспільстві краще розуміти як довіру, яку люди поділяють і визнають ряд соціальних правил, що не обов'язково пов'язані з тим, що люди вважають основною цінністю в житті. Соціальні норми є основою соціальної довіри, при цьому норми і наші власні ідеали не обов'язково прямо з ними пов'язані. Тому це означає, що ми можемо мати соціальну довіру до людей $з$ дуже відмінними цінностями від наших власних цінностей [24, с. 1-2].

На нашу думку, вищезазначені взаємозв'язки між соціальними нормами та соціальною довірою мають визначальне значення для сучасного демократичного суспільства 3 цінностями рівних прав і свобод людей, відсутністю дискримінації, адже означають можливість співпраці заради досягнення спільних суспільних цілей незалежно від особистих цінностей. Це є підгрунтям до розвитку 
громадянського суспільства за умови соціальної довіри у суспільстві різних людей.

Соціальна довіра часто інтерпретується як щось таке, що можна заслужити, якщо вести себе відповідним чином - відповідально та компетентно.

Якщо коротко, то судження про соціальну довіру грунтуються на доказах. [2, с. 7] Крім того, соціальна довіра повязана також і 3 вихованням. Вітчизняні ж дослідники-педагоги говорять про важливість виховання громадянина-патріота ще з юнацтва, як на цьому наголошував ще В. О. Сухомлинський. Його нова система виховання заснована, з-поміж іншого, на розумінні моральних цінностей, усвідомлення і переживання моральних понять у реальних взаєминах з людьми. Особливий же акцент робився вченим на розвиток почуття любові, відповідальності та обов'язку щодо свого народу [20, с. 572]. Таке виховання молоді, вважаємо, сприяє формуванню у молоді активної громадянської позиції щодо розвитку і добробуту свого суспільства, соціальної довіри.

Західні дослідники Т. Ерл та Т. Цвєтковіч досліджували соціальну довіру як шлях до космополітського суспільства ще у 1990-х роках. Вони визначають соціальну довіру у загальному розумінні як процес, за допомогою якого люди покладають на інших осіб, групи чи установи відповідальність за виконання певних завдань [2, с. 3]. Таке визначення чітко пов'язане з діяльністю органів публічної влади та довірою до них.

Більш того, за спостереженнями Т. Ерла та Т. Цвєтковіча, обговорення соціальної довіри урядовцями або критиками 3 незалежних сторін, як правило, починається з провалів політики невдач, причини яких пояснюються публічною опозицією або небажанням співпрацювати. Як правило, публічні управлінці та критики говорять про те, що проблема полягає у тому, що існує значна соціальна недовіра, або, якщо говорити по-іншому, - занадто мало соціальної довіри. [2, с. 4] Таким чином, успіх у реалізації різних напрямів публічної політики у сучасному демократичному суспільстві різними його акторами, у тому числі представниками публічної влади, пов'язують $з$ рівнем соціальної довіри. 
Відзначимо, що соціальна довіра грунтується на впевненості у надійності соціального об'єкта, що заснована на уявленні або знаннях про нього і пов'язана зі здатністю передбачати, прогнозувати чи впливати на дії цього об'єкта, контролювати його діяльність. Уявлення про об'єкт формується на основі досвіду взаємодії з ним, а також у процесі комунікації, коли інформація про об'єкт транслюється безпосередньо іншими людьми або опосередковано через мас-медіа, книги, фільми, мережу Інтернет, соціальні мережі тощо. Отже, соціальна довіра базується на синтезі власного та групового досвіду уявлення про об'єкт і пов'язана 3 певними очікуваннями відносно нього. [23]

На думку Н. Паніної, авторки моніторингового дослідження Інституту соціології Національної Академії Наук України «Українське суспільство: динаміка соціальних змін», у якому щорічно відстежують показники довіри громадян до інших людей i соціальних інститутів, соціальна довіра - це одна із головних умов консолідації суспільства, а ефективним шляхом іï підвищення $\epsilon$ перехід від контролю держави над суспільством і особистістю до контролю громадянського суспільства відносно органів публічної влади і механізмів публічного управління економікою. [23]

Досвід публічного управління в умовах демократизації суспільного життя і розвитку ринкової економіки свідчить про неефективність традиційних організаційно-управлінських засобів і заходів та про необхідність пошуку нових шляхів вирішення питань управління, що відповідають складності сучасних викликів i стратегій розвитку України. Характер взаємовідносин між представниками органів публічної влади й громадянами може бути різним. У тому числі, це - довіра до владних структур, надія на захист, допомогу, підтримку в складних життєвих ситуаціях громадян по відношенню до влади й здатність влади (або іiі нездатність) відповідати цим очікуванням. Кредит довіри до влади залежить від характеру реальних взаємодій, які складаються між владою і громадянами. У результаті дослідження вчені дійшли висновку, що низький рівень довіри громадян до органів публічної влади обумовлюється особливостями функціонування соціального 
діалогу в сучасних умовах, який скоріше $є$ ширмою для цілей, часом протилежних соціальному партнерству. Тому організація діалогу між владою і громадянами, хоча є складним процесом, але його постійне ініціювання двома сторонами стане стимулом до поступового формування громадської думки про основні механізми, форми і методи досягнення політичного консенсусу, соціальної солідарності та інтеграції в суспільстві [10, с. 103-104, 108].

На думку С. Головахи, «реальний шлях підвищення довіри у суспільстві - це послідовний перехід від контролю держави над суспільством і особистістю до послідовного контролю громадянського суспільства відносно державного апарату та його методів управління соціально-політичною сферою і економікою» [4, с. 10]. Таким чином, можна говорити про необхідність участі громадян у формуванні і реалізації публічних політик, виконання громадянами функції контролінгу над діяльністю органів публічної влади. Це підвищить і рівень соціальної довіри до органів публічної влади, і буде ознакою розвитку громадянського суспільства.

Однак, українське суспільство протягом останніх років залишається одним 3 найбільш незадоволених i найбільш недовірливих у Європі. Так, 73 \% українського населення зовсім не вірить у можливість змін на краще. Причиною такого становища вчені і практики вважають постійні переструктурування політичного простору в Україні. Кожна політична сила, отримуючи кредит довіри на виборах, намагається узаконити свої ідеї суспільно-політичного розвитку країни, нівелюючи при цьому всі інші [5].

Відповідно перейдемо до аналізу рівня соціальної довіри до органів публічної влади в Україні згідно 3 соціологічними опитуваннями різних міжнародних і вітчизняних організацій.

Дослідженню соціальної довіри сприяють міжнародні моніторингові проєкти, такі як: World Values Survey (Світове дослідження цінностей), European Social Survey (Свропейське соціальне дослідження); Eurobarometer (Свробарометр) тощо, а також українські опитування, які проводить Інститут соціології НАН України, Центр соціальних та маркетингових досліджень «СОЦИС», Київський міжнародний інститут соціології тощо. Розглянемо деякі з них. 
Наголосимо, що станом на 2019 рік українці мали найнижчий рівень довіри до уряду у світі. За результатами дослідження міжнародної асоціації Gallup, лише дев'ять відсотків громадян країни довіряють владі. Відзначимо, що цей відсоток є набагато нижче середнього рівня довіри до уряду в пострадянських країнах, де він складає 48 відсотків, а також у середнього показника в світі (56 відсотка) у 2018 році [6].

Слід зазначити, що такий низький рівень довіри до влади фіксується в Україні вже загалом останнє десятиліття. Так, під час президентства В. Януковича, який під час Свромайдану втік до Росії і пізніше був заочно засуджений за державну зраду, рівень довіри до уряду складав $24 \%$. На початку президентства П. Порошенка з'явилися ознаки того, що глава держави почав відновлювати довіру громадян, адже на той час 24 \% мешканців були впевнені в уряді і 48 \% схвалювали роботу Президента. Однак рівень довіри до влади почав стрімко падати, оскільки українці побачили, що влада не в змозі виконати вимоги протестувальників часів Революції гідності, а також успішно провести реформи у різних галузях. У результаті вже з 2015 р. рівень довіри українців до влади не перевищував 14 \% [6].

Міжнародний моніторинговий проєкт World Values Survey (Світове дослідження цінностей) проводив у 2011 р. шосту хвилю Світового дослідження цінностей в Україні, після якого відбулася Революція гідності і окупація частини Донбасу та АР Крим. Всі ці зовнішні і внутрішні фактори впливають на отримані результати опитування Світового дослідження цінностей в Україні в межах сьомої хвилі у 2020 р. та надають можливість на сучасному етапі осмислити місце України в цінніснокультурному вимірі як на європейському просторі, так і в світі. I це дає розуміння щодо напрямів послідовного формування ціннісних орієнтирів на основі системи європейських цінностей, зокрема, - рівності перед законом, самореалізації, толерантності, відкритості змінам, індивідуальної відповідальності та взаємодопомоги.

Загалом у звіті Світового дослідження цінностей в Україні у 2020 р. вказано на такі тенденції у порівнянні з 2011 р.: 
- зростання громадської активності як фактичної, так i потенційної: зростання частоти підписання петицій, участі в громадських організаціях, готовності брати участь в демонстраціях, страйках, бойкотах;

- зниження довіри до більшості державних інституцій (суди, уряд, Верховна Рада України, освітні заклади, державні установи і служби загалом) - крім Збройних сил та Національної поліції, довіра до яких зросла. Також знизилась довіра до громадських організацій і великого бізнесу [19, с. 13-16].

Третина українців довіряє державним установам і службам та банківській системі (37,5 \% та 33,4 \%), причому довіра до державних установ знизилася у порівнянні з 2011 р. (44,4%). Судовій системі, Кабінету Міністрів України, політичним партіям та Верховній Раді України довіряє тільки приблизно один з п’яти опитаних, при цьому довіра до всіх цих політичних структур знизилась у порівнянні з 2011 р. [19, с. 62].

Представимо графічно деякі з цих результатів.

На рис. 1 представлено результати відповідей українців на питання про те, якою мірою вони довіряють державним установам та службам.

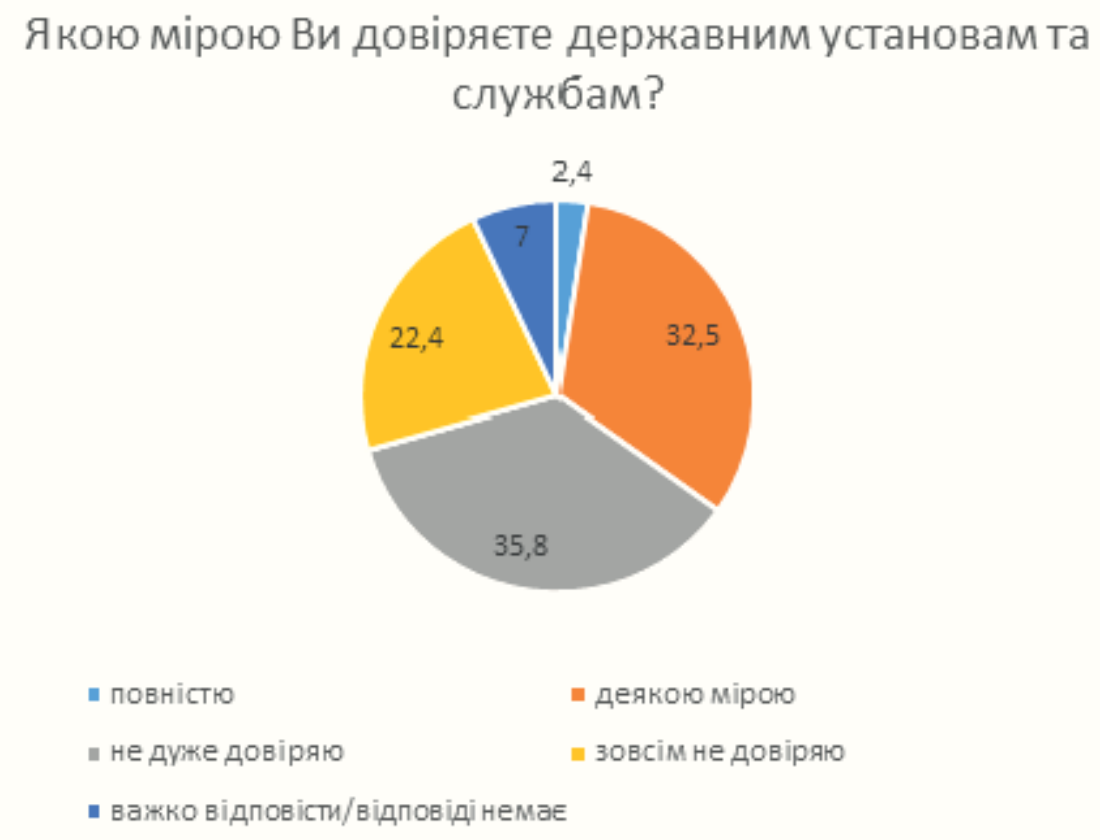

Puc. 1. Рівень довіри до державних установ та служб (2017-2020), у \% [19, с. 67]. 
Як видно з рис. 1, більше половини опитаних українців не дуже довіряють (35,8 \%) або повністю не довіряють (22,4 \%) державних установам та службам станом на 2017-2020 pp.

На рис. 2 представлено результати відповідей українців на питання про те, якою мірою вони довіряють уряду.

\section{Якою мірою Ви довіряєте уряду?}
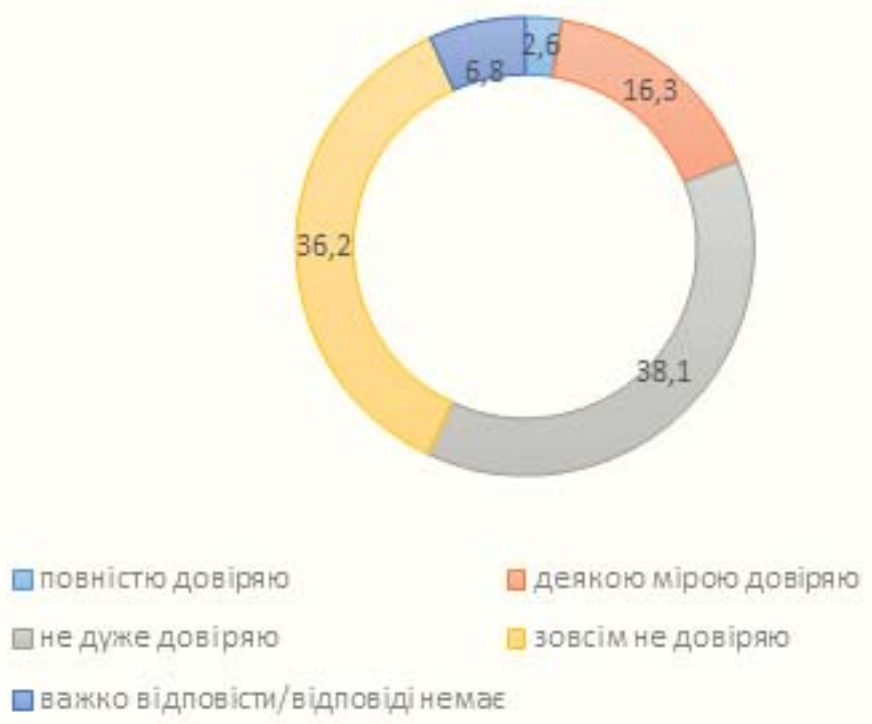

Puc. 2. Рівень довіри до уряду (2017-2020), у \% [19, с. 67].

Як видно з рис. 2 , приблизно три чверті (74,3 \%) опитаних українців не дуже довіряють (38,1 \%) або повністю не довіряють $(36,2$ \%) уряду станом на 2017-2020 pр.

Таким чином, відомий міжнародний моніторинговий проєкт World Values Survey (Світове дослідження цінностей) фіксує зниження рівня довіри до органів публічної влади, а також до громадських організацій протягом останнього десятиліття в Україні. При цьому слід зазначити, що низька довіра не тільки до влади, а й до опозиції і до громадських організацій може призвести до соціальної апатії, зниження задоволеності життям і до різних асоціальних явищ у суспільстві.

Відповідно до соціологічного опитування в Україні «Довіра до інститутів суспільства та політиків, електоральні орієнтації 
громадян України» проведеного у липні-серпні 2021 р. Центром Разумкова, серед державних та суспільних інститутів найчастіше довіра висловлюється до волонтерських організацій (64 \%), голови міста (селища, села), в якому проживає респондент (57 \%), добровольчих батальйонів $(53,5 \%)$, ради міста (селища, села), в якому проживає респондент (51\%) [1].

Наголосимо, що як показало соціологічне дослідження Центру Разумкова влітку 2021 р., один із найвищих рівнів довіри серед українців - до волонтерських організацій. При цьому зазначимо, що одним із відчутних чинників зростання локального соціального капіталу в Україні, а відтак, ознакою тенденції збільшення ресурсного потенціалу нації, $\epsilon$ посилення як стихійного, так i організованого волонтерського руху що демонструє спроможність ефективної самоорганізації та вдале залучення регіональних ресурсів дієвих мережевих об’єднань. Сплеск волонтерської активності в Україні, спричинений як зовнішньою загрозою після 2014 р., так і загалом неспроможністю держави до дієвого вирішення важливих і актуальних для країни питань, є прикладом актуалізації цінностей громадянської активності, солідарності, взаємодопомоги, відповідальності, соціального партнерства тощо, що свідчить про зростання тенденції вмотивованої гуманізації суспільного життя та посилення гостроти національної ідентичності, що в цілому сприяе розширенню генералізованої довіри, зберігаючи в той же час низькі показники інституційної довіри [8, с. 130].

Відповідно до вищезазначеного соціологічного опитування в Україні Центру Разумкова, проведеного у липні-серпні 2021 р., недовіра українцями найчастіше висловлюється державному апарату (чиновникам) (76 \%), Уряду України (72 \%) [1]. Наголосимо, що така термінологія прийнята у Центрі Разумкова, тому ми іiі приймаємо у такому формулюванні у цій роботі.

Загалом, ситуація 3 соціальною довірою та, ширше, 3 соціальним капіталом в Україні є достатньо неоднозначною. 3 одного боку, з 2014 р. в нашій державі фіксуються потужні сплески громадянської активності та соціальної довіри горизонтального рівня (як, наприклад, до волонтерських організацій, добровольчих 
батальйонів тощо), а з іншого боку - низькими $є$ показники рівня соціальної довіри до більшості інституцій, особливо до органів публічної влади.

До такого низького рівня соціальної довіри до органів публічної влади, на нашу думку, призводить також високий рівень корупції, відсутність достатньої відкритості і прозорості органів публічної влади і їх співпраці з громадянами. Так, відповідно до соціологічного опитування в Україні «Оцінка громадянами України ситуації в економічній сфері, дій влади та ролі держави в житті суспільства (травень 2021 р.)» проведеного у травні 2021 р. Центром Разумкова, громадяни мали змогу оцінити за шкалою від 1 до 5, де «1» означає «зовсім не справляється», а «5» означає, «дуже добре справляється», якою мірою влада справляється з вирішенням проблем у різних сферах. У сфері дотримання законності державними службовцями громадянами була надана оцінка 2,2 35 [13]. Тобто громадяни досить низько оцінюють дотримання принципу законності державними службовцями, а це є одним з проявів загалом низького рівня соціальної довіри до органів публічної влади в Україні.

Слідзазначити, що дієві демократичнітрансформації суспільства уможливлюється в основному не адміністративним реформуванням, а інвестиціями у виховання почуття особистої та національної гідності, професійної компетентності, відповідальності, мужності громадянської активності, готовності ризикувати, взаємного виконання зобов'язань, що реалізується у стосунках людей і стає інтегративним підгрунтям соціального капіталу. Економічна та соціальна складова локального соціального капіталу відображають можливості взаємодії горизонтального рівня - субсидіарної участі та самоорганізації громадян у вирішенні конкретних питань, безпосередньопов'язанихізпроблемамимісцевогорівня.Політичний контекст позначає вертикальні відносини - участь в управлінні муніципальною власністю, забезпечення місцевої безпеки, а також контроль громади над діяльністю владних інституцій. У цьому сенсі культура довіри передбачає також активну вертикальну недовіру як право на критику влади, вимогу іiі підзвітності та прозорості, відповідального виконання взятих зобов'язань, демонструючи 
можливості перехресного контролю, співучасті та ефективних взаємодій інституцій держави та громадянського суспільства. На думку О. Кожем'якіної, такий ракурс концептуалізації соціального капіталу передбачає розрізнення соціальної та політичної довіри, що відображають, відповідно, оцінку надійності взаємин з соціальним оточенням, та оцінку ефективності діяльності політичних інституцій. Організаційним втіленням ресурсних можливостей локального соціального капіталу $\epsilon$ інституції громадянського суспільства, дієвість яких $є$ однією з основних ознак розвитку громади, дозволяючи вирішувати локальні проблеми (наприклад, соціального захисту, територіального облаштування та ін.) без звернення до державних інституцій на основі неформальних норм [8, c. 122-123].

В Указі Президента України «Про сприяння розвитку громадянського суспільства в Україні» від 2016 р. відзначено, що активне, впливове і розвинене громадянське суспільство є важливим елементом будь-якої демократичної держави та відіграє одну з ключових ролей у впровадженні нагальних суспільних змін і належного врядування, в управлінні державними справами і вирішенні питань місцевого значення, розробці і реалізації ефективної державної політики у різних сферах, утвердженні відповідальної перед людиною правової держави, розв'язанні політичних, соціально-економічних та гуманітарних проблем. Революція Гідності відкрила новий етап в історії розвитку громадянського суспільства, продемонструвала вплив громадськості на суспільно-політичні перетворення, стала поштовхом для оновлення та переформатування влади. Як показує досвід демократичних держав, розвиток громадянського суспільства за системної державної підтримки дає змогу залучати додаткові людські, організаційні, фінансові та технічні ресурси для надання соціальних та інших суспільно значущих послуг, сприяння процесу децентралізації державного управління і підвищенню його якості, а також скоротити державні видатки і запобігти корупційним ризикам. Однак зазначається, що однією 3 основних проблем розвитку громадянського суспільства в Україні є те, що взаємодія органів державної влади, органів місцевого самоврядування 3 
громадськістю залишається малоефективною через недостатню прозорість діяльності цих органів та забюрократизовані процедури такої взаємодії, низький рівень взаємної довіри [15]. Отже, ще у 2016 р. Указом Президента України було виокремлено пріоритетний розвиток громадянського суспільства в Україні як фактор демократизації суспільства, і необхідність влади допомоги у цьому. При цьому наголошується, що через недостатню прозорість органів публічної влади, низький рівень взаємодії громадян 3 ними, існує низький рівень українців до органів публічної влади і взаємодія органів публічної влади з громадянами є малоефективною.

Відтак, публічна відповідальність безпосередньо залежить від рівня соціальної довіри, яка проявляється у підтримці публічної політики з боку громади, аж до повної втрати соціальної довіри до органів публічної влади. Особливі вимоги до відповідальності публічних інституцій базуються на їх ролі у вирішенні суспільних проблем. Неналежне або неефективне використання публічної влади призводить до втрати соціальної довіри не тільки до іï носіїв, але й до державних інститутів влади. Практичний характер, орієнтації на об'єктивні результати обумовлює особливу актуальність відповідальності в рамках політичної діяльності. Саме в цих взаємовідносинах соціальна довіра виявляється як міжособистісна довіра (між членами суспільства) і довіра до абстрактних систем (державних структур, політичних і громадських інститутів тощо). У разі високого рівня довіри в суспільстві ключові сфери життя (економіка, політика, право) функціонують значно краще, 3 більшою користю для членів суспільства. У разі ж низького їі рівня в суспільстві спостерігається соціальна напруженість, політичні i соціальні конфлікти, виникнення яких можна пояснити тим, що кожна людина має поріг довіри, а саме - той критичний момент, від якого довіра переходить у недовіру. Особливістю виникнення довіри в політиці $\epsilon$ те, що довіра виникає тут як «кредитування» суспільством політичних сил або окремих політиків. Отримуючи підтримку на виборах, політики умовно обмінюють свої зобов’язання щодо реалізації колективних цілей на довіру електорату. Якщо, наприклад, недовіра до органу державної влади 
чи політичного діяча виникає у людини відразу після невдалого спілкування з органами влади з приводу якоїсь болючої проблеми, то недовіра до політичних партій, блоків, лідерів та окремих діячів $\epsilon$ результатом особистого усвідомлення невиконання ними взятих на себе публічних зобов'язань. [14, с. 62]

Таким чином, довіра або недовіра населення до органів публічної влади є реакцією людей на ефективність їх роботи. Звідси рівень довіри громадян можна вважати одним із головних індикаторів результативності владних дій. При цьому рівень довіри населення до органів публічної влади переважно залежить від загальної оцінки їх діяльності, оскільки саме якість життя громадян значною мірою визначає ефективність роботи влади. Механізм виникнення, формування та підвищення довіри до влади з боку населення являє собою складну систему суб'єкт-суб'єктної взаємодії у вирішенні найбільш актуальних соціальних проблем та задоволенні постійно зростаючих потреб населення в умовах сучасних викликів в Україні. Суспільство з високою довірою характеризується пріоритетом суспільних цінностей і здатністю до ефективної суспільної взаємодії. Довіра також передбачає добровільне взяття на себе членами суспільства, громадянами зобов'язань щодо здійснення суспільних функцій.

Відповідно в громадянському суспільстві довіра населення формується шляхом, по-перше, забезпечення відкритості органів публічної влади задля розуміння громадянами сутності, цілей і завдань, що виникають у відповідній сфері життєдіяльності, а по-друге, ефективного вирішення актуальних проблем населення з позиції представлення більшості інтересів громадян. Тому, на переконання доктора наук з державного управління О. Серьогіна, довіру громадян до публічної влади слід розглядати, по-перше, як один з основних чинників підвищення суспільного добробуту, а подруге, - як рушійну силу ефективного суспільного розвитку через реалізацію державних реформ $[17$, с. 62,65$]$. Як зазначає кандидат наук $з$ державного управління С. Тимофєєв, «низький рівень довіри до влади, у свою чергу, зовсім не сприяє прийняттю дієвих рішень, оскільки навіть якщо вони будуть доцільні, не сприймання їх 
громадськістю в кінцевому результаті впливатиме на їх практичне впровадження» [21, с. 156].

Загалом дослідники, як було зазначено нами вище у цій роботі, вважають, що довіра пов'язана 3 попереднім досвідом - поява довірчих відносин цілком залежить від позитивного чи негативного досвіду довіри в минулому. Зазвичай негативний досвід довіри знижує готовність довіряти людям і призводить до недовіри і появи підозрілості, у тому числі й до органів публічної влади.

У контексті вищезазначеного на увагу заслуговують погляди О. Вишняка, який зазначає, що хоча довіра до політичних i державних інститутів і грунтується на ставленні до їх рішень та дій, вона не зводиться до оцінки цих рішень та дій постфактум. Важливим $є$ те, що довіра до органів публічної влади як і до інших соціальних інститутів включає в першу чергу очікування громадян щодо рішень та дій цих інститутів у майбутньому, а не тільки в минулому. Саме в цьому сенсі можна говорити про наявність чи відсутність «кредиту довіри» до певних державних чи політичних інститутів. Тому ми говоримо про те, що кредит довіри - це очікування більш позитивних дій від органів публічної влади у майбутньому, ніж вони, на думку громадян, зробили в минулому. I навпаки, відсутність кредиту довіри - це впевненість громадян у тому, що в майбутньому нічого хорошого від органів державної влади вони не очікують $[17$, с. 62,65$]$. Цей взаємозв'язок у контексті низького рівня соціальної довіри до органів публічної влади в Україні в останнє десятиліття показує те, що не лише українці мають низький рівень соціальної довіри до органів публічної влади через досвід співпраці з ними, і дії цих органів у минулому, але й те, що люди не мають позитивних очікувань у майбутньому від діяльності органів публічної влади. На нашу думку, це є ознакою системної кризи у взаємовідносинах між громадянами і органами публічної влади, а також проявом кризових явищ у суспільстві.

Висновки. У контексті забезпечення прав і свобод людини i громадянина, дотриманням принципу недискримінації за будьякими ознаками як цінностями демократичних держав у XXI столітті, результати дослідження про те, що соціальна довіра $\epsilon$ 
можливою серед людей з різними цінностями, дає більше підгрунтя до існування соціальної довіри до органів публічної влади та загалом для розвитку громадянського суспільства у сучасних полієтнічних та полікультурних державах, а також в умовах різних викликів сучасності.

Загалом оцінюючи соціальну довіру на сучасному етапі розвитку українського суспільства, можна говорити про те, що то сьогодні ситуація $є$ складною. Так, протягом останнього десятиліття відбувалося падіння рівня соціальної довіри населення до органів публічної влади, і на разі вона становить найнижчий рівень порівняно 3 іншими країнами колишнього Радянського Союзу. Українці все менше довіряють не лише владі і фінансовокредитним установам, а також навіть громадським організаціям.

Як було показано нами, такий низький рівень соціальної довіри, у тому числі, до органів публічної влади, є наслідком негативного досвіду участі громадян у довірчих відносинах 3 тими соціальними інститутами, які ми характеризували у цьому дослідженні. Більш того, взаємозв'язок у контексті низького рівня соціальної довіри до органів публічної влади в Україні в останнє десятиліття показує те, що не лише українці мають низький рівень соціальної довіри до органів публічної влади через негативний досвід співпраці з ними і неефективні дії цих органів у минулому, але й те, що люди не мають позитивних очікувань у майбутньому від діяльності органів публічної влади. Такий стан призводить до збільшення ризиків у суспільстві, зокрема для сталості реформ у всіх сферах життя.

Слід звернути увагу на те, що в останні роки в Україні збільшується соціальна довіра, відповідно до останніх соціологічних досліджень як міжнародних організацій, так й українських, до волонтерських організацій і до органів місцевого самоврядування. Це $є$ одним із позитивних аспектів реформи децентралізації, свідченням ресурсних можливостей локального соціального капіталу і дієвості громадянського суспільства на рівні розвитку громади, адже співпраця жителів громади 3 органами місцевого самоврядування, волонтерськими організаціями дозволяє 
вирішувати проблеми громади без звернення до інституцій на рівні держави.

При розвиненому громадянському суспільстві соціальна довіра населення формується через забезпечення відкритості органів публічної влади через участь громадськості у процесі прийняття, реалізації публічних політик у різних сферах, а також ефективного вирішення актуальних проблем населення. Таким чином, високий рівень соціальної довіри свідчить про розвинуте громадянське суспільство, колигромадяни через реалізацію принципів відкритості, прозорості, законності публічного управління, співпрацю з органами публічної влади, залучення до процесу формування, реалізації та оцінки публічних політик у різних сферах діють спільно з органами публічної влади заради поліпшення, у тому числі, умов свого життя в державі загалом, і в громаді, зокрема.

\section{Стаття надійшла до редакції: 30.06.21}

\section{SOCIAL TRUST IN PUBLIC AUTHORITIES AS A FACTOR OF CIVIL SOCIETY DEVELOPMENT}

Yuliana Palagnyuk, Doctor of Sciences in Public Administration, Professor, Head of Social Work, Governance and Pedagogics department, Institute of Public Administration, Petro Mohyla Black Sea National University, Mykolayiv, Ukraine.

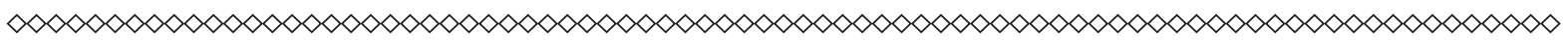

The study of the problem of social trust in various social institutions is relevant in modern Ukraine in the conditions of the occupation of Donbass's part and Crimea, the armed conflict in the east of our country, the deterioration of the socio-economic situation of citizens, ongoing reforms in various fields. Therefore, the aim of the study is to substantiate the relationship between social trust in public authorities and the development of civil society in the context of reforms in various fields in modern Ukraine. The essence of such key concepts as "trust", "social 
trust" is considered, including in the latest researches of the western scientists. The level of social trust in various social institutions in 20202021 is analyzed in accordance with the international monitoring project World Values Survey, as well as Ukrainian sociological centers. It is shown that a low level of social trust, including in public authorities, is a consequence of the negative experience of Ukrainians' participation in trusting relations with those social institutions. It is emphasized that in recent years in Ukraine there is an increase in social trust, according to the latest sociological research of both international and Ukrainian organizations, to volunteer organizations and to local governments. This is one of the positive aspects of decentralization reform, a testament to the effectiveness of civil society at the level of community development. Thus, a high level of social trust indicates a developed civil society, when citizens through the implementation of the principles of openness, transparency, legality of public administration, cooperation with public authorities, involvement in the process of formation, implementation and evaluation of public policies in various fields act together with public authorities in order to improve the conditions of their lives in the state in general, and in the community in particular.

Key words: social trust, trust, civil society, public opinion, public authority, democracy, decentralization, territorial community.

\section{Received: 30.06.2021}

\section{References}

1. Dovira do instytutiv suspilstva ta politykiv, elektoralnoyi orientatsiyi hromadyan Ukrayiny (lypen - serpen 2021 [Trust in the institutions of society and politicians, electoral orientations of the citizens of Ukraine (July-August 2021]. (n.d.) Razumkov Tsentre. Retrieved from https://razumkov.org.ua/napriamky/sotsiologichni-doslidzhennia/dovira-do-instytutiv-suspilstva-ta-politykiv-elektoralni-oriientatsii-gromadian-ukrainy [in Ukrainian].

2. Earle, Timothy C., Cvetkovich, T. George. (1995). Social trust: toward a cosmopolitan society. London: Praeger [in English]. 
3. Fukuyama, F. (2004) Doverie: sotsyalnye dobrodetely y put $k$ protsvetanyiu [Trust: The Social Virtues and the Creation of Prosperity]. Moscow, AST: Ermak [in Russian].

4. Golovaha, E., Kostenko, N., Makeeva, S. (Ed.). (2014). Obschestvo bez doveriya [Society without trust]. Kyiv: Institut sociologii. NAN Ukrainy [in Russian].

5. Golovaha, E. (2018). Yevropeyskiy vybir Ukrayiny u dzerkali hromadskoyi dumky [Ukraine's European choice in the mirror of public opinion]. Ukrayinske syspolstvo 2010-2018. Sotsiolohichiy monitoring - Ukrainian society 2010-2018. Sociological monitoring V. Vorona, M. Shulha (Ed.), In-t sotsiolohiyi NANU [in Ukrainian].

6. Hubar, O. (2019). V Ukrayini naynyzhchiy u sviti riven doviry do vlady - doslidzhennya [Ukraine has the world's lowest level of trust in government - research]. Deutsche Welle. 21.03. Retrieved from https://p. dw.com/p/3FRH1 [in Ukrainian].

7. Kostieva, T., \& Faichuk, O. (2019). Sotsialna vidpovidalnist orhaniv mistsevoho samovryaduvannya yak krok do rozvytku hromadyanskoho suspilstva (na prykladi Mykolayivskoho rayonu). [Social responsibility of local authorities as a step to the development of civil society (on the example of Mykolayiv district)]. Publichne upravlinnya ta rehionalniy rozvytok - Public Administration and Regional Development, 1(3), 57-76 [in Ukrainian]. doi: https://doi.org/10.34132/pard2019.03.04

8. Kozhemyakina, O. M. (2016). Dovira ta sotsialniy kapital: prostorova tsinnisno-normatyvna interpretatsiya [Trust and social capital: spatial value and regulatory interpretation]. Demography and Social Economy, 1 (26), 118-131 [in Ukrainian].

9. Kozhemyakina, O. M. (2017). Dovira ta solidarnist: sotsialno-filosofskiy analiz spivvidnoshennya [Trust and solidarity: a socio-philosophical analysis of the relationship] Himanitarniy visnyk - Humanitarian bulletin, Vol. 17, 1, 10-17 [in Ukrainian].

10. Kuchabskiy, O. H., \& Pohoreliy, S. S. (2013). Dovira do orhaniv publichnoyi vlady yak klyucheviy factor efetryvnosti systemy derzhavnoho upravlinnya [Trust in public authorities as a key factor in the effectiveness of public administration]. Publichne upravlinnya: teoriya i praktyka - Public management: theory and practice, 1, 103-108 [in Ukrainian]. 
11. Lypov, V. (2017). Sotsialna dovira yak tsinnist, instututsiya ta instutut [Social trust as a value, institutition and institute]. Pratsi naukovoho tovarystva im. Shevchenka. Ekonomichniy zbirnyk - Proceedings of the Scientific Society named after Shevchenko. Economic collection, Volume LI., Lviv, NTSH, 112126 [in Ukrainian].

12. Naumkina, S. M., \& Varynskiy, V. O. (2016). Mistse doviry v systemi sotsialnoho kapitalu [The place of trust in the system of social capital]. Aktualni problemy polityky - Actual problems of politics, 58, 57-65 [in Ukrainian].

13. Otsinka hromadyanamy Ukrayiny sutuatsiyi v ekonomichniy sferi, diy vlady ta roli derzhavy v zhytti suspilstva (traven 2021) [Citizens' assessment of the situation in the economic sphere, government actions and the role of the state in society (May 2021)] (n.d.) Razumkov Tsentre. Retrieved from https:// razumkov.org.ua/napriamky/sotsiologichni-doslidzhennia/otsinka-gromadianamy-ukrainy-sytuatsii-v-ekonomichnii-sferi-dii-vlady-ta-roli-derzhavy-vzhytti-suspilstva [in Ukrainian].

14. Pecherskiy, P. M. (2018). Sotsialna dovira yak osnova politychnoyi vidpovidalnosti publichnoyi vlady [Social trust as the basis of political responsibility of public authorities]. Naukoviy chasopys NPU im. M. P. Drahomanova. Ser. 22: politychni nauky ta metodyka vykladannya sotsialno-politychnikh dystsyplin - Scientific journal of NPU named after MP Drahomanov. Series 22: Political Science and Methods of Teaching Socio-Political Disciplines, Vol. 23, 61-67 [in Ukrainian].

15. Pro spryiannia rozvytku hromadianskoho suspilstva v Ukraini Ukaz Prezydenta Ukrainy vid 26 liutoho 2016 roku, 68/2016 [Promoting the development of civil society in Ukraine Decree of the President of Ukraine, February 26, 2016, 68/2016]. www.zakon.rada.gov.ua. Retrieved from: http:// zakon4.rada.gov.ua/laws/show/68/2016 [in Ukrainian].

16. Putnam, R., R. Leonardi, \& R. Nanetti (2001). Tvorennya demokratiyi: traditsiyi hromadyanskoyi aktyvnosti v suchasniy Italii [Making democracy work: civic traditions in modern Italy]. (V. Yuschenko, Trans). Kyiv: Osnovy [in Ukrainian].

17. Seriohin, S. M., \& Pysmennyi, I. V. (2015). Vidnovlennya doviry do orhanic publichnoyi vlady yak umova uspishnosti reform $\mathrm{v}$ Ukrayini [Restoring trust in public authorities as a condition for successful reforms in Ukraine]. Aspekty publichnoho upravlinnya - Aspects of public management, 4, 62-66. [in Ukrainian]. 
18. Stecenko, T.O. (2018). Dovira yak sotsialniy resurs: vid teotetychnoyi kontseptualizatsii do poshuku mekhanizmiv praktychnoho upravlinnya [Trust as a social resourse: from theoretical conceptualization to the search for mechanisms of practical governance]. HRANI-EDGES. Vols 21, 6, 44-78 [in Ukrainian].

19. Svitove doslidzhennya tsinnostey 2020 v Ukrayini [Global values review] (2020). Ukrayinskiy tsentr yevropeyskoyi polityky - Ukrainian Center for European Policy, Kyiv Retrieved from http://ucep.org.ua/wp-content/ uploads/2020/11/WVS_UA_2020_report_WEB.pdf [in Ukrainian].

20. Surgova, S. \& Faichuk, O. (2020) V. O. Sukhomlynsky Educational System as a Forming Basis for Personality Moral Qualities (On the occasion of the 100th birthday). Pedagogy. Bulgarian Journal of Educational Research and Practice, Vol. 92, 4, 569-577 [in English].

21. Tymofieiev, S. P. (2021) Perspektyvy pidvyschennya rivnya doviry do orhaniv publichnoyi vlady v Ukrayini [Prospects for increasing the level of trust in public authorities in Ukraine]. Naukovi perspektyvy - Scientfic prospects, 6(12), 149-162 [in Ukrainian]. doi: https://doi.org/10.52058/2708-75302021-6(12)-1

22. Ukaz Prezydenta Ukrainy Pro tsili staloho rozvytku Ukrainy na period do 2030 roku : vydanyi 30 ver. 2019 roku \# 722/2019 [Decree Of The President Of Ukraine About the Goals of sustainable development of Ukraine for the period up to 2030 from Sep. 302019 \# 722/2019] (2019, September 2019). www.president.org.ua. Retrieved from https://www.president.gov.ua/ documents/7222019-29825 [in Ukrainian].

23. Ursulenko, K. V. (2006) Dovira sotsialna [Social trust]. Entsykopediya suchasnoyi Ukrayiny: elektronna versiya - Encyclopedia of modern Ukraine: electronic version. I. M. Dzyuba, A. I. Zhukovskiy, M. H. Zheleznnyak et al. Retvieved from https://esu.com.ua/search_articles.php?id=20476 [in Ukrainian].

24. Vallier, K., \& Weber, M. (Ed.) (2021) Social trust. New York, NY: Routledge [in English]. 
Відомості про автора / Information about the Author

Палагнюк Юліана Вікторівна: Чорноморський національний університет імені Петра Могили вул. 68 Десантників 10, Миколаїв, 54003, Україна.

Yuliana Palagnyuk: Petro Mohyla Black Sea National University: 68 Desantnykiv, 10, Mykolayiv, 54003, Ukraine.

ORCID. ORG./ 0000-0003-1019-8498

E-mail: yulianna_p@hotmail.com 